$\underline{\beta}=-m$

\title{
Determination of some metals in the commonly consumed dairy products randomly collected from the market in Alexandria - Egypt, with an emphasis on toxicity, permissible limits and risk assessment
}

\author{
Sahar Y Issa ${ }^{1,3 *}$, Doaa M Genena ${ }^{2}$, Maha K Al Mazroua ${ }^{3}$, Safaa M Abdel Rahman ${ }^{4}$, Marwa M Fawzi ${ }^{5}$ \\ ${ }^{1}$ Department of Forensic Medicine and clinical Toxicology-Faculty of Medicine, Alexandria University \\ ${ }^{2}$ Medical Research Institute - Alexandria University \\ ${ }^{3}$ Regional Poison control center, Dammam-Saudi Arabia \\ ${ }^{4}$ Central Laboratory, Alexandria, Egypt \\ ${ }^{5}$ Department of Forensic Medicine and clinical Toxicology-Faculty of Medicine, Ain-Shams University \\ *Corresponding author E-mail: sahar_issa71@yahoo.com
}

\begin{abstract}
The aim of this research was to evaluate the possible contamination by heavy metals of 30 random samples of raw milk and four other dairy products (pasteurized milk, white cheese, yellow cheese, and yoghurt), that were purchased from the three different regions in Alexandria, Egypt namely; (Eastern, Central and Western Alexandria). Each sample was homogenized, powdered, and mineralized in a microwave oven. Quantitative analyses of $\mathrm{Al}, \mathrm{Se}, \mathrm{Zn}, \mathrm{Cd}, \mathrm{Cu}$ and $\mathrm{Pb}$ were performed using an inductively coupled plasma-mass (ICPMS) spectrometry. Western Alexandria samples had the highest recorded levels in $\mathrm{Pb}, \mathrm{Cd}$ and $\mathrm{Cu}$ (7.421 ppm, and $0.673 \mathrm{ppm}$, and 5.013 ppm) consecutively. Highest levels detected for $\mathrm{Al}$ and Se were detected in samples collected from Eastern Alexandria (2.74 ppm and $0.093 \mathrm{ppm})$ successively. Zn (31.64 ppm) showed the highest concentration in a sample purchased from Central Alexandria. Further investigations of the levels of metals in bigger number of milk samples from different zones of Alexandria, Egypt are necessary, both to examine this problem from the toxicological, clinical, and epidemiological point of view and, to assess the exposure risk.
\end{abstract}

Keywords: Toxicity; ICP-MS; Heavy Metals; Milk; Dairy Products ; Risk Assessment; Egypt.

\section{Introduction}

The existence of heavy metals in the environment is considered as a major concern because of their toxicity and threat to human life as well as environment. (Katzi TG et al. 2009, Bilandzic N et al. 2011) Dairy products provide a great sense of eating pleasure due to their flavor and nice taste. Milk and dairy products are considered important foods regarding their protein and mineral contents essential for promoting the growth and maintenance of human life. (Katzi TG et al. 2009) Trace elements in foodstuffs are of significant importance because of their essential or toxic effect. Milk is known as an excellent source of $\mathrm{Ca}$, and it can supply moderate amounts of $\mathrm{Mg}$, smaller quantity of $\mathrm{Zn}$ and very small contents of $\mathrm{Fe}$ and $\mathrm{Cu}$. (Bilandzic N et al. 2011, Rahimi E 2013) On the other hand, due to the developing environment pollution induced by industrial, and agricultural pollutions; milk and dairy products contain different amounts of toxic contaminants. (Ataro A et al 2008, Karimi $\mathrm{H}$ et al. 2008, Bilandzic N et al. 2011) Consequently, it is also mandatory to determine and monitor the levels of these toxic metals (TMs) in milk and dairy products, because they are for the most part consumed by infants and children and, can significantly influence their health. The determination of TMs level in milk is particularly monitored by international organizations. (Steijns JM 2001, Licata P et al. 2004) Many reports indi- cated the presence of heavy metals in milk and other food products. (Caggiano R et al. 2005, Tuzen M et al. 2008)

$\mathrm{Cu}, \mathrm{Zn}$ and $\mathrm{Se}$ are essential metals for normal function of our body, however, from the toxicological point of view, their intake in higher amounts above safe recommended levels may be risky to the human health. (Licata P et al. 2012) It is well-known that the $\mathrm{Cd}$ and $\mathrm{Pb}$ have the greatest injurious effects on renal tissue and nervous system, respectively. (Neal AP and Guilarte TR 2013) Contamination of dairy products with Aluminum may result from the environment, but the concentration of this element increases notably with processing, packaging and food additives. (Damond $\mathrm{J}$ 2005) There is a strong connection between Aluminum and Alzheimer's syndrome. Besides Alzheimer's, toxic levels of Aluminum has also been associated with Parkinson's disease. Chronic Aluminum exposure has contributed directly to hepatic failure and dementia. (Canadian Study of Health and Aging 2002) The determination of trace inorganic constituents in milk and dairy products is not an easy task due to their complex emulsion like matrices and low concentration levels of the metal ions. Most proposed procedures involve a step of digestion to eliminate the organic matrixes, which may involve several steps and contamination can become a serious obstacle for obtaining accurate data of trace quantities of elements. (Tuzen M and Soylak M 2007, Karimi H et al. 2008) Several analytical methods have been reported for the determination of trace metals in milk and dairy products including: inductively coupled plasma-mass (ICP-MS) spectrometry(Licata P et al. 
2004) or, atomic absorption spectroscopy (AAS).(Freschi GP et al. 2012) Knowing the cumulative effect of heavy metals and, from the toxicological and, dietary points of view, it is essential to assign the amount and absorption of heavy metals in milk and its products and compare the results with the permissible international limits, to be able to assess risk of exposure. Hegart PV in 2008, stated that in order to evaluate risk assessment through dietary exposure to metals, many parameters have to be estimated, namely; provisional tolerable daily intake (PTDI), provisional tolerable weakly intake (PTWI) and provisional tolerable monthly intake (PTMI).

\section{Aim of the work}

To evaluate the levels of some metal content among different dairy products collected from the open market in Alexandria, Egypt. Also, to compare the results with international standards regarding the permissible limits; and assess exposure to heavy metals due to the consumption of milk and other dairy products.

\section{Material and methods}

30 random samples of raw milk (RM), and four other dairy products \{pasteurized milk (PM), white cheese (WC), yellow cheese(YC), and yoghurt(Y)\} were randomly purchased from supermarkets in the three different regions in Alexandria, Egypt namely; (Eastern, Central and Western Alexandria). Sample preparation and analysis will be conducted; the samples will then be analyzed for some metals content ( $\mathrm{Al}, \mathrm{Se}, \mathrm{Zn}, \mathrm{Cd}, \mathrm{Cu}$ and $\mathrm{Pb}$ ) using inductively coupled plasma-mass (ICP-MS) spectrometry according to the procedure described by Jalbani N. et al. in 2009. The mean concentrations of the metals will be compared with the international permissible limits. Risk assessment by dietary exposure to metals through milk and dairy products consumption will be studied.

\subsection{Chemicals}

All the reagents and chemicals Merck (Darmstadt, Germany) were used of analytical grade. De-ionized water was used throughout the work. Concentrated nitric acid (65\%), were spectroscopic grades Merck (Darmstadt, Germany).

\subsection{Apparatus}

Inductively Coupled Plasma Mass Spectrometry (ICP-MS), after microwave acid digestion was used in measurements of studied metals.

\subsection{Sampling and analysis}

30 random samples of raw milk and four other dairy products (pasteurized milk, white cheese, yellow cheese, and yoghurt) were purchased from supermarkets in the three different regions in Alexandria, Egypt namely; (Eastern, Central and Western Alexandria) in Alexandria city, Egypt during the year 2015. Samples were conditioned in sterile plastic container and kept at $4{ }^{\circ} \mathrm{C}$ until analyses that were carried out in same day.

\subsection{Sample preparation}

Six elements ( $\mathrm{Al}, \mathrm{Se}, \mathrm{Zn}, \mathrm{Cd}, \mathrm{Cu}$ and $\mathrm{Pb}$ ) were determined in each dairy product samples. Prior to analysis samples must be decomposed with the appropriate methods procedure with digest containing reduced amounts of carbon residues. In order to minimize the effects of the organic matrix, closed vessel acid decomposition in microwave oven system was used. Moreover, it may provide faster, more efficient process and reduce or eliminate the risk of sample contamination and losses of analytes. A microwave assistedacid digestion procedure was carried out, in order to achieve a shorter digestion time and using minimum amount of acid. Duplicate of $2.0 \mathrm{~mL}$ of each dairy product samples were taken into microwave vessels but well shaken, opened and sampled by pouring directly from the original container into the microwave vessel. Added the samples to each vessels and $10 \mathrm{~mL}$ of a concentrated $\mathrm{HNO} 3-\mathrm{H} 2 \mathrm{O} 2(2: 1, \mathrm{v} / \mathrm{v})$ and kept samples for $10 \mathrm{~min}$ at room temperature till the samples were homogenized, and then placed the vessels in covered PTFE container. This was then heated following a one-stage digestion programmed at $80 \%$ of total power $(900$ $\mathrm{W})$, for 3 - $5 \mathrm{~min}$. After cooling, the resulting solutions were evaporated to semidried mass to remove an excess acid, and then diluted up to $50.0 \mathrm{~mL}$ in volumetric flasks and kept as a stock sample solution, and were analysed using methodology given by Jalbani N. et al. in 2009. ${ }^{(17)}$

\subsection{Statistical analysis}

Statistical analysis was performed using SPSS statistical software (version 15; SPSS, Chicago, IL). Data were expressed as minimum, maximum and, mean \pm standard deviations (SD).

\section{Results}

Comparison between Concentration ranges in $\mathrm{mg} / \mathrm{kg}(\mathrm{ppm})$ of metals in different dairy products $(\mathrm{n}=30$ for each sampling site) purchased from Alexandria, Egypt were given in table (1). Western Alexandria samples had the highest recorded levels in $\mathrm{Pb}, \mathrm{Cd}$ and $\mathrm{Cu}(7.421 \mathrm{ppm}$, and $0.673 \mathrm{ppm}$, and $5.013 \mathrm{ppm})$ consecutively. Highest levels detected for $\mathrm{Al}$ and Se were detected in samples collected from Eastern Alexandria (2.74 ppm and $0.093 \mathrm{ppm}$ ) successively. Zn showed the highest concentration in a sample purchased from Central Alexandria (31.64 ppm). The accepted daily intake (ADI) of $\mathrm{Pb}, \mathrm{Cd}, \mathrm{Al}, \mathrm{Cu}, \mathrm{Zn}$ and $\mathrm{Se}$ and mean concentration of these metals in all studied samples compared to their calculated daily intake from consumption of $200 \mathrm{ml}$ milk or $200 \mathrm{~g}$ dairy product per day based on a caloric intake of 2,000 calories diet were presented in table (2). Pb had the highest calculated daily intake from consumption of $200 \mathrm{ml}$ milk or $200 \mathrm{~g}$ dairy product per day $(98.1 \%)$, while $\mathrm{Al}$ had the least calculated value $(0.12 \%)$.

Table 1: Concentration Ranges in $\mathrm{Mg} / \mathrm{Kg}(\mathrm{Ppm})$ of Metal in Milk, and Dairy Products Samples ( $\mathrm{N}=30$ for Each Sampling Site)

\begin{tabular}{|c|c|c|c|c|c|c|c|c|c|c|c|c|c|c|c|c|}
\hline \multirow{2}{*}{\multicolumn{2}{|c|}{ Metal }} & \multicolumn{5}{|c|}{ Eastern Alexandria } & \multicolumn{5}{|c|}{ Central Alexandria } & \multicolumn{5}{|c|}{ Western Alexandria } \\
\hline & & RM & PM & WC & $\mathrm{YC}$ & $\mathrm{Y}$ & RM & PM & WC & $\mathrm{YC}$ & $\mathrm{Y}$ & RM & PM & WC & YC & $\mathrm{Y}$ \\
\hline \multirow{3}{*}{$\mathrm{Al}$} & $\begin{array}{l}\text { Mini- } \\
\text { mum }\end{array}$ & 0.33 & 0.14 & 0.25 & 1.01 & 0.24 & 0.41 & 0.54 & 0.84 & 0.42 & 0.12 & 0.51 & 0.52 & 0.64 & 0.45 & 0.17 \\
\hline & $\begin{array}{l}\text { Maxi- } \\
\text { mum }\end{array}$ & 2.50 & 2.61 & 1.91 & 2.74 & 1.42 & 2.31 & 1.92 & 2.20 & 2.51 & 1.84 & 2.11 & 1.42 & 2.60 & 2.54 & 1.89 \\
\hline & $\begin{array}{l}\text { Mean } \pm \\
\text { SD }\end{array}$ & $\begin{array}{l}0.501 \\
\pm \\
0.107\end{array}$ & $\begin{array}{l}1.324 \\
\pm \\
0.112\end{array}$ & $\begin{array}{l}1.324 \\
\pm \\
0.112\end{array}$ & $\begin{array}{l}0.403 \\
\pm \\
0.114\end{array}$ & $\begin{array}{l}1.021 \\
\pm \\
0.121\end{array}$ & $\begin{array}{l}0.320 \\
\pm \\
0.112\end{array}$ & $\begin{array}{l}0.303 \\
\pm \\
0.121\end{array}$ & $\begin{array}{l}1.221 \\
\pm \\
0.100\end{array}$ & $\begin{array}{l}1.230 \\
\pm \\
0.152\end{array}$ & $\begin{array}{l}0.306 \\
\pm \\
0.104\end{array}$ & $\begin{array}{l}1.121 \\
\pm \\
0.111\end{array}$ & $\begin{array}{l}1.420 \\
\pm \\
0.137\end{array}$ & $\begin{array}{l}0.414 \\
\pm \\
0.141\end{array}$ & $\begin{array}{l}1.111 \\
\pm \\
0.012\end{array}$ & $\begin{array}{l}1.304 \\
\pm \\
0.152\end{array}$ \\
\hline \multirow[b]{2}{*}{$\mathrm{Se}$} & $\begin{array}{l}\text { Mini- } \\
\text { mum }\end{array}$ & 0.010 & 0.012 & 0.005 & 0.005 & 0.011 & 0.002 & 0.003 & 0.004 & 0.002 & 0.001 & 0.015 & 0.015 & 0.006 & 0.011 & 0.015 \\
\hline & $\begin{array}{l}\text { Maxi- } \\
\text { mum }\end{array}$ & 0.080 & 0.029 & 0.025 & 0.093 & 0.019 & 0.021 & 0.040 & 0.011 & 0.035 & 0.062 & 0.010 & 0.045 & 0.050 & 0.042 & 0.034 \\
\hline
\end{tabular}




\begin{tabular}{|c|c|c|c|c|c|c|c|c|c|c|c|c|c|c|c|c|}
\hline & $\begin{array}{l}\text { Mean } \pm \\
\text { SD }\end{array}$ & $\begin{array}{l}0.016 \\
\pm \\
0.003\end{array}$ & $\begin{array}{l}0.018 \\
\pm \\
0.002\end{array}$ & $\begin{array}{l}0.014 \\
\pm \\
0.001\end{array}$ & $\begin{array}{l}0.016 \\
\pm \\
0.003\end{array}$ & $\begin{array}{l}0.016 \\
\pm \\
0.001\end{array}$ & $\begin{array}{l}0.011 \\
\pm \\
0.010\end{array}$ & $\begin{array}{l}0.012 \\
\pm \\
0.003\end{array}$ & $\begin{array}{l}0.015 \\
\pm \\
0.002\end{array}$ & $\begin{array}{l}0.013 \\
\pm \\
0.001\end{array}$ & $\begin{array}{l}0.012 \\
\pm \\
0.003\end{array}$ & $\begin{array}{l}0.018 \\
\pm \\
0.001\end{array}$ & $\begin{array}{l}0.016 \\
\pm \\
0.001\end{array}$ & $\begin{array}{l}0.012 \\
\pm \\
0.002\end{array}$ & $\begin{array}{l}0.014 \\
\pm \\
0.002\end{array}$ & $\begin{array}{l}0.016 \\
\pm \\
0.001\end{array}$ \\
\hline \multirow{3}{*}{$\begin{array}{l}\mathrm{Z} \\
\mathrm{n}\end{array}$} & $\begin{array}{l}\text { Mini- } \\
\text { mum }\end{array}$ & 1.740 & 1.621 & 2.300 & 2.690 & 2.650 & 1.610 & 1.631 & 2.311 & 2.601 & 2.621 & 1.742 & 1.541 & 2.420 & 2.890 & 2.545 \\
\hline & $\begin{array}{l}\text { Maxi- } \\
\text { mum }\end{array}$ & 7.414 & 15.84 & 31.60 & 14.30 & 14.04 & 6.421 & 12.84 & 31.64 & 15.30 & 12.07 & 7.114 & 15.04 & 21.56 & 17.70 & 22.04 \\
\hline & $\begin{array}{l}\text { Mean } \pm \\
\text { SD }\end{array}$ & $\begin{array}{l}4.770 \\
\pm \\
1.524 \\
\end{array}$ & $\begin{array}{l}6.796 \\
\pm \\
3.740 \\
\end{array}$ & $\begin{array}{l}10.75 \\
\pm \\
6.749 \\
\end{array}$ & $\begin{array}{l}8.178 \\
\pm \\
4.108 \\
\end{array}$ & $\begin{array}{l}5.520 \\
\pm \\
2.492 \\
\end{array}$ & $\begin{array}{l}4.970 \\
\pm \\
1.312 \\
\end{array}$ & $\begin{array}{l}7.701 \\
\pm \\
2.940 \\
\end{array}$ & $\begin{array}{l}10.75 \\
\pm \\
6.749 \\
\end{array}$ & $\begin{array}{l}8.178 \\
\pm \\
4.108 \\
\end{array}$ & $\begin{array}{l}5.520 \\
\pm \\
2.492 \\
\end{array}$ & $\begin{array}{l}4.570 \\
\pm \\
1.614 \\
\end{array}$ & $\begin{array}{l}6.196 \\
\pm \\
3.241 \\
\end{array}$ & $\begin{array}{l}8.75 \\
\pm \\
6.749 \\
\end{array}$ & $\begin{array}{l}6.178 \\
\pm \\
4.118 \\
\end{array}$ & $\begin{array}{l}9.520 \\
\pm \\
2.492\end{array}$ \\
\hline \multirow{3}{*}{$\begin{array}{l}\mathrm{C} \\
\mathrm{d}\end{array}$} & $\begin{array}{l}\text { Mini- } \\
\text { mum }\end{array}$ & 0.004 & 0.034 & 0.052 & 0.085 & 0.110 & 0.014 & 0.054 & 0.071 & 0.085 & 0.110 & 0.007 & 0.039 & 0.072 & 0.035 & 0.112 \\
\hline & $\begin{array}{l}\text { Maxi- } \\
\text { mum }\end{array}$ & 0.516 & 0.672 & 0.618 & 0.290 & 0.598 & 0.321 & 0.611 & 0.662 & 0.290 & 0.598 & 0.516 & 0.673 & 0.614 & 0.210 & 0.538 \\
\hline & $\begin{array}{l}\text { Mean } \pm \\
\text { SD }\end{array}$ & $\begin{array}{l}0.288 \\
\pm \\
0.161\end{array}$ & $\begin{array}{l}0.278 \\
\pm \\
0.186 \\
\end{array}$ & $\begin{array}{l}0.200 \\
\pm \\
0.137\end{array}$ & $\begin{array}{l}0.223 \\
\pm \\
0.056\end{array}$ & $\begin{array}{l}0.239 \\
\pm \\
0.102\end{array}$ & $\begin{array}{l}0.284 \\
\pm \\
0.158\end{array}$ & $\begin{array}{l}0.268 \\
\pm \\
0.174\end{array}$ & $\begin{array}{l}0.241 \\
\pm \\
0.167\end{array}$ & $\begin{array}{l}0.232 \\
\pm \\
0.044\end{array}$ & $\begin{array}{l}0.219 \\
\pm \\
0.110\end{array}$ & $\begin{array}{l}0.256 \\
\pm \\
0.132\end{array}$ & $\begin{array}{l}0.291 \\
\pm \\
0.184\end{array}$ & $\begin{array}{l}0.217 \\
\pm \\
0.135\end{array}$ & $\begin{array}{l}0.236 \\
\pm \\
0.156\end{array}$ & $\begin{array}{l}0.215 \\
\pm \\
0.101\end{array}$ \\
\hline \multirow{3}{*}{$\begin{array}{l}\mathrm{C} \\
\mathrm{u}\end{array}$} & $\begin{array}{l}\text { Mini- } \\
\text { mum }\end{array}$ & 1.437 & 0.091 & 0.722 & 0.235 & 0.016 & 1.414 & 0.093 & 0.715 & 0.232 & 0.014 & 1.415 & 0.087 & 0.385 & 0.215 & 0.016 \\
\hline & $\begin{array}{l}\text { Maxi- } \\
\text { mum }\end{array}$ & 5.002 & 2.439 & 2.592 & 2.037 & 1.640 & 5.010 & 2.421 & 2.162 & 2.018 & 1.672 & 5.013 & 2.414 & 3.590 & 4.032 & 1.940 \\
\hline & $\begin{array}{l}\text { Mean } \pm \\
\text { SD }\end{array}$ & $\begin{array}{l}2.836 \\
\pm \\
1.094 \\
\end{array}$ & $\begin{array}{l}1.505 \\
\pm \\
0.703 \\
\end{array}$ & $\begin{array}{l}1.379 \\
\pm \\
0.447 \\
\end{array}$ & $\begin{array}{l}0.899 \\
\pm \\
0.451 \\
\end{array}$ & $\begin{array}{l}0.623 \\
\pm \\
0.420\end{array}$ & $\begin{array}{l}2.814 \\
\pm \\
1.107 \\
\end{array}$ & $\begin{array}{l}1.512 \\
\pm \\
0.627 \\
\end{array}$ & $\begin{array}{l}1.324 \\
\pm \\
0.487 \\
\end{array}$ & $\begin{array}{l}0.864 \\
\pm \\
0.416\end{array}$ & $\begin{array}{l}0.671 \\
\pm \\
0.411 \\
\end{array}$ & $\begin{array}{l}2.732 \\
\pm \\
1.091 \\
\end{array}$ & $\begin{array}{l}1.905 \\
\pm \\
0.752 \\
\end{array}$ & $\begin{array}{l}1.364 \\
\pm \\
0.412 \\
\end{array}$ & $\begin{array}{l}0.852 \\
\pm \\
0.418 \\
\end{array}$ & $\begin{array}{l}0.663 \\
\pm \\
0.435\end{array}$ \\
\hline \multirow{3}{*}{$\begin{array}{l}P \\
b\end{array}$} & $\begin{array}{l}\text { Mini- } \\
\text { mum }\end{array}$ & 0.018 & 0.742 & 0.298 & 1.600 & 0.270 & 0.019 & 0.727 & 0.273 & 1.635 & 0.270 & 0.019 & 0.642 & 0.271 & 1.920 & 0.259 \\
\hline & $\begin{array}{l}\text { Maxi- } \\
\text { mum }\end{array}$ & 6.754 & 5.805 & 5.416 & 7.015 & 5.400 & 7.054 & 6.015 & 5.926 & 7.011 & 5.381 & 5.724 & 5.254 & 7.421 & 7.011 & 5.353 \\
\hline & $\begin{array}{l}\text { Mean } \pm \\
\text { SD }\end{array}$ & $\begin{array}{l}1.850 \\
\pm \\
1.557 \\
\end{array}$ & $\begin{array}{l}3.500 \\
\pm \\
1.517\end{array}$ & $\begin{array}{l}2.900 \\
\pm \\
1.287 \\
\end{array}$ & $\begin{array}{l}4.404 \\
\pm \\
1.607 \\
\end{array}$ & $\begin{array}{l}3.053 \\
\pm \\
1.305\end{array}$ & $\begin{array}{l}1.950 \\
\pm \\
1.335 \\
\end{array}$ & $\begin{array}{l}3.540 \\
\pm \\
1.521\end{array}$ & $\begin{array}{l}2.870 \\
\pm \\
1.247\end{array}$ & $\begin{array}{l}3.904 \\
\pm \\
1.621\end{array}$ & $\begin{array}{l}3.102 \\
\pm \\
1.105\end{array}$ & $\begin{array}{l}1.812 \\
\pm \\
1.521 \\
\end{array}$ & $\begin{array}{l}2.501 \\
\pm \\
1.350 \\
\end{array}$ & $\begin{array}{l}2.840 \\
\pm \\
1.287\end{array}$ & $\begin{array}{l}4.404 \\
\pm \\
1.607\end{array}$ & $\begin{array}{l}3.051 \\
\pm \\
1.612\end{array}$ \\
\hline
\end{tabular}

Table 2: The Accepted Daily Intake (ADI) of $\mathrm{Pb}, \mathrm{Cd}, \mathrm{Al}, \mathrm{Cu}, \mathrm{Zn}$ and Se and Mean Concentration of These Metals in All Studied Samples Compared to Their Calculated Daily Intake from Consumption of $200 \mathrm{Ml}$ Milk or $200 \mathrm{G}$ Dairy Product Per Day Based on A Caloric Intake of 2,000 Calories Diet.

\begin{tabular}{|c|c|c|c|c|}
\hline \multirow[t]{2}{*}{ Metals } & \multirow[t]{2}{*}{$\begin{array}{l}\text { ADI } \\
\mu \mathrm{g} / 70 \mathrm{~kg} \\
\text { person }\end{array}$} & \multirow[t]{2}{*}{$\begin{array}{l}\text { Mean concentration of metals }(\mathrm{ppm}= \\
\mu \mathrm{g} / \mathrm{ml}) \text { in all examined samples }\end{array}$} & \multicolumn{2}{|c|}{$\begin{array}{l}\text { Calculated daily intake of metals from consumption of } 200 \mathrm{ml} \text { milk or } 200 \mathrm{~g} \\
\text { dairy product per day based on a caloric intake of } 2,000 \text { calories \& calculat- } \\
\text { ed percentage of ADI. }\end{array}$} \\
\hline & & & $\mu \mathrm{g} /$ day / person & $\%$ \\
\hline Lead $(\mathrm{Pb})$ & $252^{a}$ & 3.541 & 247.87 & 98.01 \\
\hline $\begin{array}{l}\text { Cadmium } \\
\text { (Cd) }\end{array}$ & $70^{\mathrm{a}}$ & 0.212 & 14.84 & 21.2 \\
\hline $\begin{array}{l}\text { Aluminium } \\
\text { (Al) }\end{array}$ & $70,000^{\mathrm{a}}$ & 1.211 & 84.77 & 0.12 \\
\hline Copper & $35,000^{b}$ & 1.532 & 107.24 & 0.31 \\
\hline Zinc & $70,000^{b}$ & 6.965 & 487.55 & 0.69 \\
\hline $\begin{array}{l}\text { Selenium } \\
(\mathrm{Se})\end{array}$ & $400^{b}$ & 0.151 & 10.57 & 2.64 \\
\hline
\end{tabular}

a) : WHO, 2006

b) :FDA, January 2013

\section{Discussion}

The safety of dairy products ends when toxic compounds and environmental pollutants (especially heavy metals) concentrations increase. Detection, estimation and comparison of heavy metals levels in dairy products with standard, are needed to establish their safety. (Hegart PV 2008) This issue has been a subject of several studies all over last decades. (WHO 2006) The highest detected values for toxic metals in the current study were those of $\mathrm{Pb}$ (7.421 ppm), while the lowest concentrations were of $\mathrm{Cd}(0.004$ ppm).

Al had a highest detected level of (2.74 ppm). As for the essential metals, Se and Zn had highest levels of (0.09 ppm and $31.64 \mathrm{ppm})$ consecutively, followed by $\mathrm{Cu}$ (5.013 ppm). Malhat et al. in 2012 reported lead and cadmium had mean levels of 4.404 and 0.288 ppm correspondingly, in cow milk collected from different sites in El-Qaliubiya governorate, Egypt. These levels are less than values detected in the current study for $\mathrm{Pb}$ and $\mathrm{Cd}$ simultaneously (7.421, and $5.013 \mathrm{ppm}$ ). Fatima et al. in 2005, reported that the $\mathrm{Pb}$ was determined in their studied samples, but with concentrations well below the limit defined by WHO in 2006. Based on the notifications from the Agency for Toxic Substances and Disease Registry (ASTDR 2006), regarding the determination of the maximum levels of contaminants in food products, $\mathrm{Al}$ content should not exceed $15 \mathrm{mg} / \mathrm{kg}$. (ASTDR 2006) According to many authors,
$\mathrm{Al}$ dietary intake must not exceed $6 \mathrm{mg} /$ day to avoid its potentially toxic effects. (Ysart G et al. 2000, Navaro I and Alvarez JI 2003) Dietary Al intake in USA was estimated by Pennington and Schoen in 1995, to be $0.7-11.5 \mathrm{mg} /$ day in children, $8-9 \mathrm{mg} /$ day in adult males and $7 \mathrm{mg} /$ day in adult females. Ysart et al. in 2000 estimated the mean dietary $\mathrm{Al}$ intake in the United Kingdom as 3.4 $\mathrm{mg} /$ day. A tolerable daily intake (TDI) for $\mathrm{Al}$ of $1 \mathrm{mg} / \mathrm{kg}$ of body weight per day has been established by an international committee of experts under the auspices of the WHO in 2006.

Lead content in cheese samples are usually high due to the $\mathrm{Pb}$ binding characteristic of casein. Because of the preferential affinity of metals for the amount of the casein fraction in milk, the concentration of the metals in yoghurt is lower when compared to milk. (Coni E et al. 1996)

Ayar A et al. in 2009 analyzed $\mathrm{Pb}$ concentration dairy products and milk consumed in Turkey. According to their study the concentration range of $\mathrm{Pb}$ was reported as $0.09-0.19 \mathrm{mg} / \mathrm{kg}$. In another study, conducted by Tajkarimi et al in 2008 , lead content was estimated in raw milk collected from different regions of Iran. Accordingly, the mean level of $\mathrm{Pb}$ content obtained from 97 samples had a range from 1.0 to $46 \mathrm{ng} / \mathrm{mL}$. These results are by far less than $\mathrm{Pb}$ levels in the current study that ranged between 0.018 $7.421 \mathrm{mg} / \mathrm{kg}$.

The mean concentrations of $\mathrm{Cd}$ in the analyzed milk and dairy products in the current study ranged between 0.004 and $0.672 \mathrm{mg} /$ 
$\mathrm{kg}$. This is more than the levels recorded by Rahimi E in 2013, where $\mathrm{Cd}$ concentrations in cow milks collected from different regions in Iran ranged between 0.92 to $0.74 \mathrm{ng} / \mathrm{mL}$.

Additionally, Ayar et al. in 2009 reported the concentration of $\mathrm{Cd}$ in raw milk, yoghurt and white cheese as $0.002-0.03,0-0.33$ and $0-0.038 \mathrm{mg} / \mathrm{kg}$, respectively, which are less than results, recorded in the current study. The main sources of $\mathrm{Cd}$ in animal feed in domestic animals are crops, trace element premixes, fish meal and minerals such as, limestone and phosphate. (Bilandzic $\mathrm{N}$ et al. 2011) The maximum permissible level of $\mathrm{Cd}$ in dairy products has been reported to be $0.02 \mathrm{mg} / \mathrm{kg}$ of wet weight in Turkey and 1.0 $\mathrm{mg} / \mathrm{kg}$ of wet weight in Malaysia. (Ayar A et al. 2009, Food Law of Ministry of Health, Malaysia in 2010).

Trace elements such as $\mathrm{Cu}, \mathrm{Se}$ and $\mathrm{Zn}$, are known to have vital role in normal growth. But when the amount of intake exceeds the determined levels, they may produce toxic effects. ${ }^{(32)}$ Our data demonstrated that the $\mathrm{Zn}$ content in raw and pasteurized milk samples were lower than those reported by Licata et al. and Soares et al. in 2010. The content of $\mathrm{Cu}$ in raw milk was less than the amount reported by Bilandzic et al. in 2011, and Licata et al. in 2012; but more than those reported by Khan et al. in 2014 The content of Se was less than that given for milk and dairy products in the research conducted by Ayar, et al. (2009) in Turkey Large amounts of Se can have injurious consequences on our health such as hair loss, brittle nails and many other side effects.

The mean $\mathrm{Zn}$ concentrations in the current study ranged between (1.541-22.04). In another study conducted on milk samples collected from great Cairo over on year, its level ranged from 4.1 to $5.45 \mathrm{ppm}$ with an average $4.25 \mathrm{ppm}$. (Malhat F et al. 2012) Concentrations of $\mathrm{Zn}$ were less than the normal levels adopted by the Japanese; $4 \mathrm{mg} / \mathrm{kg}$, and Chinese; $2.5-6.7 \mathrm{mg} / \mathrm{kg}$. (Qin L et al. 2009) This parameter is important because $\mathrm{Zn}$ has many functions in the body and its deficiency leads to disruption in different physiological functions. (Soares VA et al. 2010) $\mathrm{Cu}$ contents in the present study were slightly higher when compared with the Japanese and Chinese standards. (Qin L et al. 2009) Apart from the lead which was so close to maximum permissible limit, all products examined, were not even close to permissible levels of other metals analyzed.

\section{Conclusions}

Toxic adverse health effect due to the consumption of milk and dairy products in Alexandria, Egypt are unlikely in long term exposure consumers. Egypt must have annual risk assessment evaluating programs in food safety. This would bring Egypt into line with international best practices in food safety, increasing the efficiency and effectiveness of food safety programs along the entire Egyptian food chain, including food imports, food exports and the tourist industry. This will also allow food analysis laboratories to build expertise and facilities to analyse foods based on food safety risks and, finally Egyptian consumers can be more confident of the safety of the Egyptian food supply in their market. Additionally, it is suggested that subsequent studies should be conducted on heavy metals contamination in different stages of milk industrial preparation to find out factors that might be involved in heavy metals contamination.

\section{References}

[1] Ataro A, McCrindle R I, and Botha B M, et al. (2008): Quantification of trace elements in raw cow's milk by inductively coupled plasma mass spectrometry (ICP-MS). Food Chemistry, 111, 243-8. http://dx.doi.org/10.1016/j.foodchem.2008.03.056.

[2] ATSDR - Agency for Toxic Substances and Disease Registry (2006): Public health statement Aluminum CAS number; 7429: 905.

[3] Ayar A, Sert D, and Akin N (2009): The trace metal levels in milk and dairy products consumed in middle Anatolia - Turkey. Environmental Monitoring and Assessment, 152(1-4); 1-12 http://dx.doi.org/10.1007/s10661-008-0291-9.
[4] Bilandzic N, Dokic M, and Sedak M, et al. (2011): Trace element levels in raw milk from northern and southern regions of Croatia. Food Chemistry 127(1) : 63-6. http://dx.doi.org/10.1016/j.foodchem.2010.12.084.

[5] Caggiano R, Sabia S, and D'Emilio M, et al. (2005): Metal levels in fodder, milk, dairy products, and tissues sampled in ovine farms of

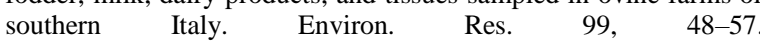
http://dx.doi.org/10.1016/j.envres.2004.11.002.

[6] Canadian Study of Health and Aging, (2002): Risk factors for Alzheimer's disease. Arn. J. Epidemiol., 156: 445-53. http://dx.doi.org/10.1093/aje/kwf074.

[7] Coni E, Bocca A, and Coppolelli P, et al. (1996): Minor and trace element content in sheep and goat milk and dairy products. Food Chemistry. 57(2); 253-60. http://dx.doi.org/10.1016/03088146(95)00216-2.

[8] Damond J (2005): A report on Alzheimer's disease and current research. Alzheimer Society of Canada Revised.

[9] FDA; Food and Drug Administration (2013): Dietary Reference Intakes for Vitamin A, Vitamin K, Arsenic, Boron, Chromium, Copper, Iodine, Iron, Manganese, Molybdenum, Nickel, Silicon, Vanadium, and Zinc. Report of the Panel on Micronutrients. National Academy Press, Washington, DC, Food and Drug Administration. Dietary supplements. Center for Food Safety and Applied Nutrition.

[10] Food law of Ministry of Health Malaysia, (2010): Food Safety Standards. In Major export markets: A readymade guide for agro exporters (p. 28).

[11] Freschi G P, Fortunato F M, and Freschi C D, et al. (2012): Simultaneous and direct determination of $\mathrm{As}, \mathrm{Bi}, \mathrm{Pb}, \mathrm{Sb}$, and $\mathrm{Se}$ and $\mathrm{Co}$, $\mathrm{Cr}, \mathrm{Cu}, \mathrm{Fe}$, and $\mathrm{Mn}$ in milk by electro thermal atomic absorption spectrometry. Food Analytical Methods, 5(4), 861- 6 http://dx.doi.org/10.1007/s12161-011-9323-0.

[12] Hegart PV, (2008): Risk assessment in the food safety agency (FSA). Technical assistance for policy reform II. USAID/Egypt policy and private sector office.

[13] Jalbani N, Kazi TG and Hassan I (2009): Determination of toxic metals in different brand of chocolates and candies, marketed in Pakistan. Pakistan Journal of Analytical \& Environmental Chemistry, $10,48-52$.

[14] Karimi H, Ghaedi M, and Shokrollahi A, et al. (2008): Development of a selective and sensitive flotation method for determination of trace amounts of cobalt, nickel, copper and iron in environmental samples. J. Hazard. Mater; 151, 26-32. http://dx.doi.org/10.1016/j.jhazmat.2007.05.051.

[15] Kazi TG, Jalbani N, and Baig JA, et al. (2009): Assessment of toxic metals in raw and processed milk samples using electrothermal atomic absorption spectrophotometer. Food and Chemical Toxicology, 47, 2163-9. http://dx.doi.org/10.1016/j.fct.2009.05.035.

[16] Khan N, Jeong I S, and Hwang I M, et al. (2014): Analysis of minor and trace elements in milk and yogurts by inductively coupled plasma-mass spectrometry (ICP-MS). Food Chemistry. 147; 220-4. http://dx.doi.org/10.1016/j.foodchem.2013.09.147.

[17] Licata P, Di Bella G, and Potortì A, et al. (2012): Determination of trace elements in goat and bovine milk from Calabria (Italy) by ICP- AES. Food Additives and Contaminants: Part B, 5(4), 268-71. http://dx.doi.org/10.1080/19393210.2012.705335.

[18] Licata P, Trombetta D, and Cristani M, et al. (2004): Levels of "toxic" and "essential" metals in samples of bovine milk from various dairy farms in Calabria, Italy. Environ. Int. 30, 1-6. http://dx.doi.org/10.1016/S0160-4120(03)00139-9.

[19] Malhat F, Hagag M, and Saber A, et al. (2012): Contamination of Cows Milk by Heavy Metal in Egypt; Bulletin of Environmental Contamination and Toxicology: (88); 611-3. http://dx.doi.org/10.1007/s00128-012-0550-x.

[20] Navaro I and Alvarez JI (2003): Aluminum content of Spanish infant formula. Food Additives and Contaminants, 20: 470-81. http://dx.doi.org/10.1080/0265203031000098704.

[21] Neal AP and Guilarte TR (2013): Mechanisms of lead and manganese neurotoxicity. 561 Toxicology research, 2(2), 99-114 http://dx.doi.org/10.1039/c2tx20064c.

[22] Pennington JA and Schoen SA (1995): Estimates of dietary exposure to aluminum. Food Addit Contam; 12: 119-28. http://dx.doi.org/10.1080/02652039509374286.

[23] Qin L, Wang X, and Li W, et al. (2009): The minerals and heavy metals in cow's milk from China and Japan. Journal of Health Science, 55(2); 300-5. http://dx.doi.org/10.1248/jhs.55.300.

[24] Rahimi E. (2013): Lead and cadmium concentrations in goat, cow, sheep, and buffalo milks from different regions of Iran. Food Chemistry, 136, 389-91. http://dx.doi.org/10.1016/j.foodchem.2012.09.016. 
[25] Salah F, Esmat I, and Mohamed A (2013): Heavy metals residues and trace elements in milk powder marketed in Dakahlia Governorate. International Food Research Journal. 20(4); 1807-12.

[26] Soares VA, Kus MM, and Peixoto AL, et al. (2010): Determination of nutritional and toxic elements in pasteurized bovine milk from Vale do Paraiba region (Brazil). Food Control, 21(1); 45-9. http://dx.doi.org/10.1016/j.foodcont.2009.03.010.

[27] Steijns JM (2001): Milk ingredients as nutraceuticals. Int. J. Dairy Technol. $\quad 54, \quad 81-\quad 8 . \quad$ http://dx.doi.org/10.1046/j.1364727x.2001.00019.x.

[28] Tajkarimi M, Ahmadi FM, and Poursoltani H, et al. (2008): Lead residue levels in raw milk from different regions of Iran. Food Control; 19(5);

http://dx.doi.org/10.1016/j.foodcont.2007.05.015.

[29] Tuzen M and Soylak M (2007): Evaluation of trace element contents in canned foods marketed from Turkey. Food Chem. 102, 1089-95. http://dx.doi.org/10.1016/j.foodchem.2006.06.048.

[30] Tuzen M, Saracoglu S, and Soylak M (2008): Evaluation of trace element contents of powdered beverages from Turkey. J. Food Nutr. Res. 47, 120-4.

[31] WHO; World Health Organization (2006): Evaluation of Certain Food Additives and Contaminants; 33rd Report of the Joint FAO/WHO Expert Committee on Food Additives; Technical Report Series 776. WHO, Geneva.

[32] Ysart G, Miller P, and Croasdale M, et al. (2000): Total diet study-dietary exposures to Aluminum, arsenic, cadmium, chromium, copper, lead, mercury, nickel, selenium, tin and zinc.
Add
Contam.
17; $\quad 775-86$

http://dx.doi.org/10.1080/026520300415327. 